\begin{tabular}{|c|c|c|}
\hline $\begin{array}{l}\text { OPEN ACCESS } \\
\text { Vol. } 4 \text { No. 2: } 58-70 \\
\text { Tahun 2021 } \\
\text { Artikel penelitian 圈 }\end{array}$ & $\begin{array}{l}\text { Jurreal Alkudutililestari } \\
\text { E-ISSN: 2598-8204 } \\
\text { http://ojs.umrah.ac.id/index.php/akuatiklestari } \\
\text { DOI: https://doi.org/10.31629/akuatiklestari.v4i2.2468 }\end{array}$ & $\frac{1}{\vdots=}$ \\
\hline
\end{tabular}

\title{
Produksi Serasah dan Laju Dekomposisi Thalassia hemprichii dan Cymodocea rotundata di Perairan Malang Rapat, Kabupaten Bintan
}

\author{
Litter Production and Thalassia hemprichii and Cymodocea rotundata Decomposition Rates in the \\ waters of Malang Rapat Waters, Bintan Regency
}

\section{Kariska Kristiana ${ }^{1 \bowtie}$, Febrianti Lestari ${ }^{1}$, Aditya Hikmat Nugraha ${ }^{2}$}

1 Manajemen Sumberdaya Perairan, Fakultas Ilmu Kelautan dan Perikanan, Universitas Maritim Raja Ali Haji, Tanjungpinang, Indonesia 29111

2 Ilmu Kelautan, Fakultas Ilmu Kelautan dan Perikanan, Universitas Maritim Raja Ali Haji, Tanjungpinang, Indonesia 29111

\section{$\square$ Info Artikel:}

Diterima: 18 Agustus 2021

Revisi: 20 Januari 2021

Disetujui: 27 Mei 2021

Dipublikasi: 30 Mei 2021

[1] Keyword:

Tutupan lamun, Produksi Serasah, Laju dekomposisi, Perairan Malang Rapat

\footnotetext{
$\bowtie$ Penulis Korespondensi:

Kariska Kristiana

Manajemen Sumberdaya Perairan Fakultas IImu Kelautan dan Perikanan, Universitas Maritim Raja Ali Haji Tanjungpinang, Indonesa 29111

Email: kariskakristiana@gmail.com
}

\begin{abstract}
ABSTRAK. Tujuan penelitian ini adalah mengetahui tutupan jenis $T$. hemprichii dan C. rotundata, mengetahui produksi jenis $T$. hemprichii dan $C$. rotundata dan mengetahui laju dekomposisi lamun jenis $T$. hemprichii dan C. rotundata. Penelitian ini di lakukan dengan metode purposive sampling. Hasil penelitian tutupan lamun di Perairan Desa Malang Rapat Kecamatan Gunung Kijang Kabupaten Bintan stasiun satu jenis T. hemprichii dengan tutupan lamun perjenis sebesar $8,51 \%$, sedangkan C. rotundata $8,50 \%$. Jika dilihat dari nilai total tutupan lamun sebesar $39,4 \%$ dikategorikan sedang, stasiun dua tutupan lamun perjenis $T$. hemprichii berkisar $6,41 \%$, sedangakan C. rotundata berkisar 5,65\% dan total tutupan sebesar 29,49\%. Produksi serasah di Perairan Desa Malang Rapat Kecamatan Gunung Kijang Kabupaten Bintan pada stasiun satu $T$. hemprichii dan C. rotundata mengalami kenaikan dibandingkan pada stasiun dua. Laju dekomposisi pada stasiun dua $T$. hemprichii dan C. rotundata mengalami laju dekomposisi lebih cepat dibandingkan stasiun satu.
\end{abstract}

\begin{abstract}
The purpose of this study was to determine the cover of $T$. hemprichii and $C$. rotundata types, to know the production of $T$. hemprichii and $C$. rotundata species and to determine the rate of decomposition of seagrass species of $T$. hemprichii and $C$. rotundata. This research was conducted with a purposive sampling method. The results of the study of seagrass cover in the waters of Malang waters, Gunung Kijang Subdistrict, Bintan Regency, one type T. hemprichii station with seagrass cover of $8.51 \%$, while $C$. rotundata $8.50 \%$. If seen from the total seagrass cover value of $39.4 \%$ is categorized as medium, the station two of seagrass cover types of $T$. hemprichii is around $6.41 \%$, while $C$. rotundata is around $5.65 \%$ and total cover is $29.49 \%$. Litter production in the waters of Malang waters, Gunung Kijang Subdistrict, Bintan Regency at station $T$. hemprichii and $C$. rotundata increased compared to station two. The decomposition rate at station two $T$. hemprichii and $C$. rotundata experienced a faster rate of decomposition than station one.
\end{abstract}

\section{PENDAHULUAN}

Desa Malang Rapat merupakan salah satu Desa di Kabupaten Bintan yang termasuk ke dalam wilayah pesisir. yang memiliki berbagai keanekaragaman hayati yang sangat tinggi seperti mangrove, lamun, dan terumbu karang. Perairan Desa Malang Rapat termasuk ke dalam kawasan konservasi padang lamun yang ada di Pulau Bintan (BPS Kabupaten Bintan, 2015). Lamun adalah bagian dari ekosistem yang ditemukan dipesisir daerah dan satu satunya tanaman berbunga yang dapat hidup terendam di air laut. Lamun di Indonesia ditemukan di daerah pesisir dan pulau-pulau kecil yang dapat hidup sampai kedalaman 40 meter. Lamun hidup pada substrat pasir, lumpur berpasir, terdapat 14 spesies dari 69 spesies ditemukan di dunia (Kawaroe et al., 2016). Dari 7 spesies hanya 2 spesies sering di temukan di perairan timur Pulau Bintan yaitu Enhalus acoroides, Thalassia hemprichii, Cymodocea rotundata, Cymodocea serrulata, Halodule uninervis, Halophila ovalis dan Syringodium isoetifolium (Supriyadi et al., 2018).

Lamun secara ekologis memiliki fungsi penting pada daerah pesisir, antara lain sebagai produsen primer pada perairan dangkal, daerah pembesaran, pemijahan dan juga merupakan sumber makanan penting bagi beberapa jenis organisme (dalam bentuk detritus), selain itu lamun juga dapat berfungsi sebagai penyedia nutrien untuk biota, menstabilkan sedimen dasar melalui model perakaran yang menjalar dan padat (Asmidar, 2015). Serasah memiliki peran dalam penyedia nutrien, kandungan nutrien yang ada di perairan dipengaruhi oleh hasil dekomposisi serasah. Serasah 
akan terdekomposisi dan menghasilkan bahan organik yang terbawa oleh arus dan dapat memperkaya ke ekosistem sekitarnya (Hutomo \& Azkab, 1987). Penelitian yang dilakukan akan mengkaji terkait produksi serasah dan laju dekomposisi dari lamun jenis T. hemprichii dan C. rotundata karena jenis ini banyak ditemukan pada setiap lokasi penelitian dibandingkan jenis yang lainnya. Tujuan penelitian ini adalah mengetahui tutupan jenis T. hemprichii dan C. rotundata, mengetahui produksi jenis T. hemprichii dan C. rotundata dan mengetahui laju dekomposisi lamun jenis T. hemprichii dan $C$. rotundata.

\section{BAHAN DAN METODE}

\subsection{Waktu dan Tempat}

Penelitian ini dilaksanakan pada bulan Februari-Mei 2020, pengambilan sampel serta pengukuran parameter dilakukan di Perairan Desa Malang Rapat Kecamatan Gunung Kijang Kabupaten Bintan. Analisis laboratorium dilakukan di Laboratorium Riset Fakultas Ilmu Kelautan dan Perikanan Universitas Maritim Raja Ali Haji, Senggarang, Kota Tanjungpinang, analisis sampel nutrien dianalisis di Laboratorium Lingkungan PT Surveyor Indonesia Kota Batam. Adapun peta lokasi penelitian dapat dilihat pada Gambar 1.
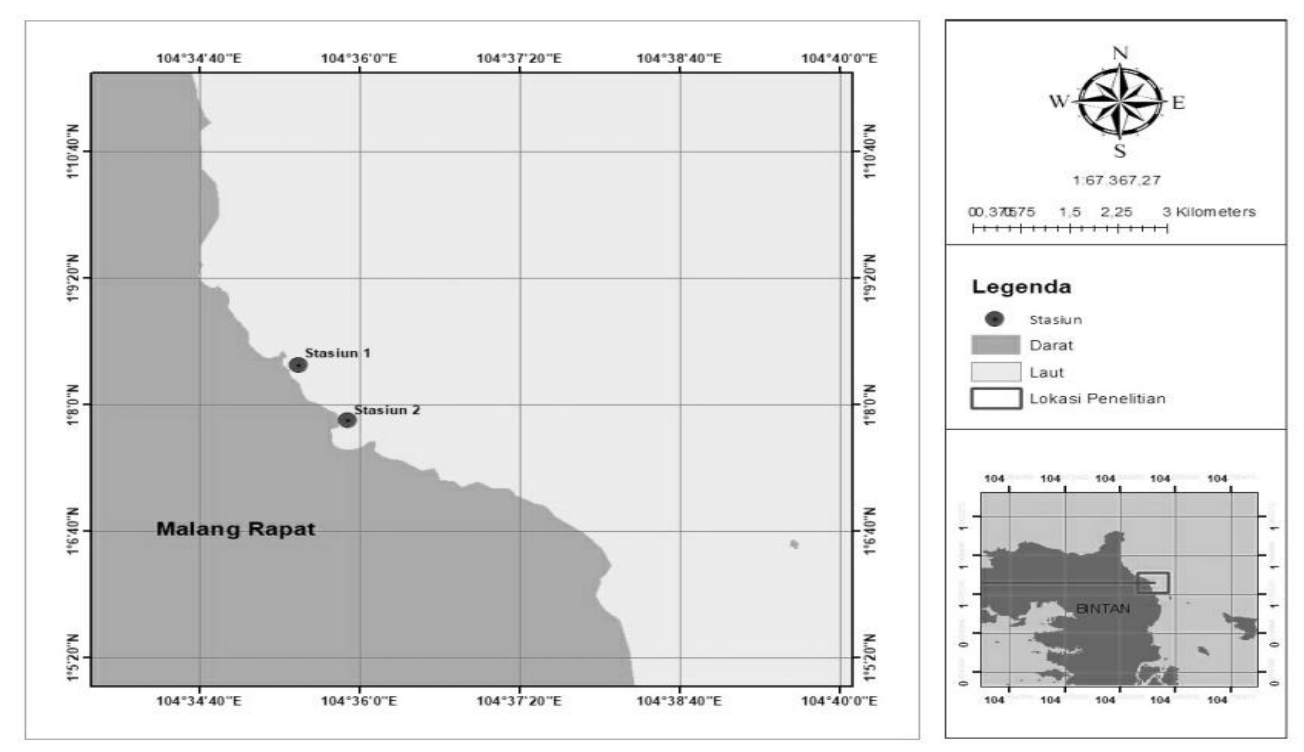

Gambar 1. Peta Lokasi Penelitian (Google earth)

\subsection{Alat dan Bahan}

Alat dan bahan yang digunakan dalam penelitian ini meliputi alat multitester untuk mengukur DO, pH dan suhu, Hand refractometer untuk mengukur salinitas, secchi disk untuk mengukur kecerahan, roll meter untuk menentukan jarak antar titik stasiun, GPS (Global Positioning System) menentukan titik koordinat antar stasiun pengamatan, Transek kuadrat $(50 \times 50 \mathrm{~cm})$ untuk mengamati jenis lamun yang ditemukan, alat tulis dan kertas untuk mencatat hasil pengamatan, kamera digital untuk dokumentasi, buku identifikasi untuk identifikasi jenis lamun, platik sampel untuk tempat sampel ynag dijumpai, kertas label untuk penamaan sampel, aquades untuk membilas peralatan, botol sampel untuk tempat sampel, oven untuk mengeringkan substrat dan serasah lamun, timbangan digital untuk menimbang substrat, ayakan bertingkat untuk penyakan substrat, perangkap serasah lamun untuk menampung serasah, tongkat berskala mengukur kedalaman, lamun objek penelitian.

\subsection{Prosedur Penelitian}

\subsubsection{Teknik Pengumpulan Data}

Metode yang digunakan dalam penelitian ini adalah metode survei, yaitu dengan pengamatan langsung dimana pengambilan data menggunakan teknik purposive sampling. Data primer didapatkan dari observasi langsung di lapangan berupa identifikasi jenis dan tutupan, serta pengukuran parameter lingkungan perairan yaitu: suhu, salinitas, $\mathrm{pH}$, kecerahan, DO, kedalaman, nitrat, fosfat dan substrat. Hasil dari analisis data primer akan ditabulasikan dalam tabel dan dideskripsikan dengan data yang ada dengan literatur, sedangkan data sekunder bisa didapatkan dari Kantor Desa Malang Rapat.

\subsubsection{Penentuan Stasiun dan Titik Sampling}

Penelitian ini dilakukan pada Perairan Desa Malang Rapat Kecamatan Gunung Kijang Kabupaten Bintan. Penentuan titik sampling ditentukan dengan metode purposive sampling yaitu berdasarkan perbedaan karakteristik dari setiap stasiun ditemukanya lamun. Stasiun satu terletak di posisi titik koordinat N $01.06602^{\circ}$, E $104.37922^{\circ}$ memiliki 
karakteristik perairan yang jernih, terletak di daerah dengan pengaruh aktivitas wisata pantai, sedangkan pada stasiun

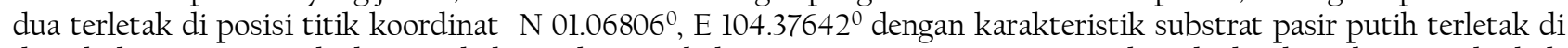
daerah dengan pengaruh aktivitas kelong, aktivitas bekarang, menjaring, memancing, berada di sekitar buangan limbah tambak udang dan masukan dari air tawar, dengan intensitas karakteristik perairan yang lebih tinggi dibandingkan stasiun satu.

\subsubsection{Pengamatan Tutupan Lamun}

Metode yang digunakan untuk menghitung tutupan lamun adalah metode transek garis, yang umum dipakai dalam pengamatan struktur komunitas padang lamun. Satu stasiun terdapat tiga transek garis dimana masing-masing transek garis panjangnya 100 meter jarak antar transek garis $50 \mathrm{~m}$. Transek kuadrat diletakkan mulai pertama kali ditemukanya lamun. Sepanjang 100 meter ini pengamatan lamun dilakukan dengan bantuan transek kuadrat berukuran $50 x 50 \mathrm{~cm}$ diletakkan pada titik 0 hingga 100 dengan interval 10 meter. Ilustrasi transek pengamatan tutupan lamun dapat di lihat pada Gambar 2.

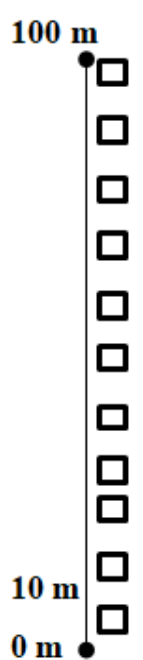

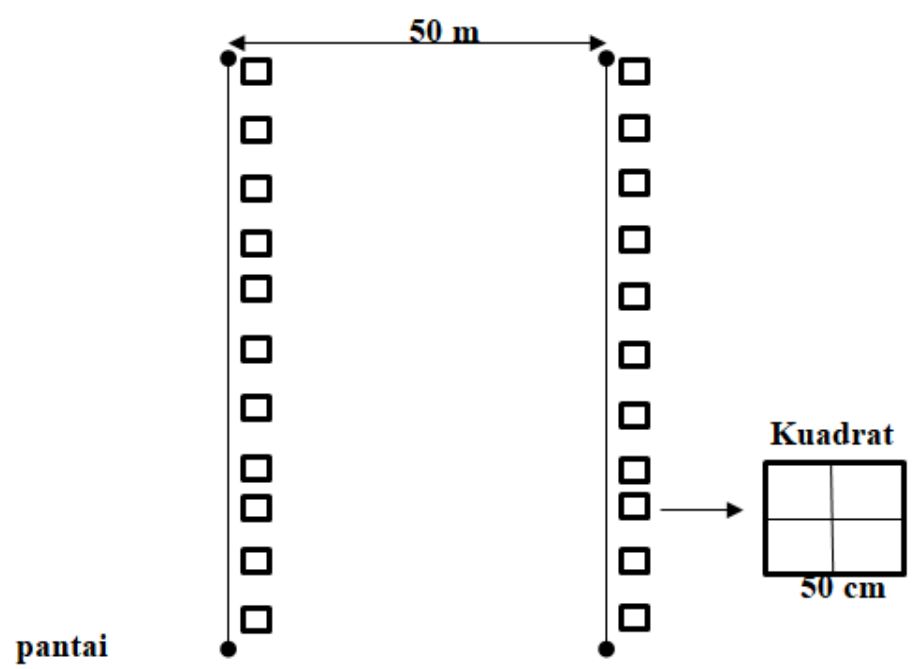

Gambar 2. Line Transek Kuadran

\subsubsection{Pengamatan Produksi Serasah}

Pengumpulan serasah lamun dilakukan menggunakan perangkap jaring (serasah). Jaring perangkap serasah dengan berukuran 50 × $50 \mathrm{~cm}$ (Gambar 3). Terdapat tiga perangkap pada tiap stasiun, Dasar perairan dibersihkan terlebih dahulu dari organisme benthos sebelum dilakukanya pengurungan sampel lamun yang diambil adalah bagian daun yang melayang maupun yang berada di dasar substrat (Awaliah, 2016). Serasah yang terapung dan tenggelam dikumpulkan selama pengamatan yang dilakukan pertujuh hari selama satu bulan. Sampel yang terkumpul kemudian dimasukkan kedalam kantong sampel untuk dibawa ke laboratorium. Sampel yang telah diambil dibersihkan untuk menghilangkan epifit kemudian sampel serasah dikeringkan pada suhu $80^{\circ} \mathrm{C}$ selama dua hari mencapai berat konstan (Faiqoh et al., 2018).

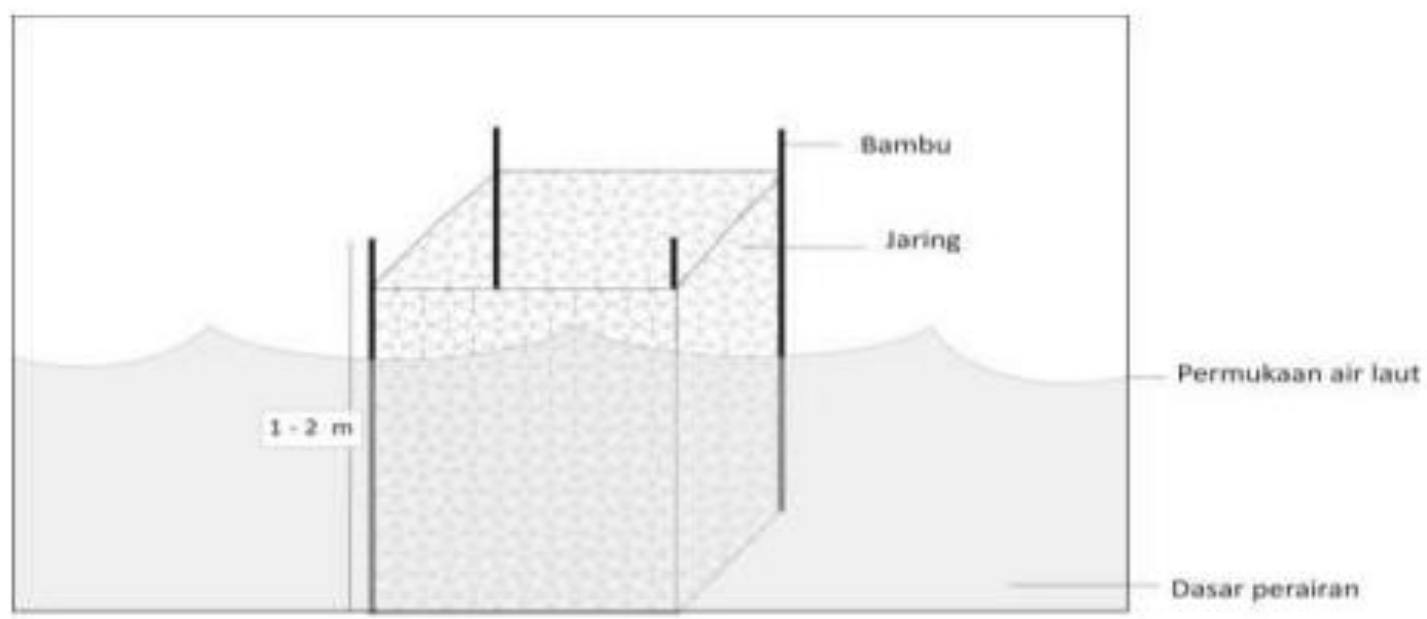

Gambar 3. Jaring Perangkap Serasah 


\subsubsection{Pengamatan Laju Dekomposisi Serasah}

Serasah yang telah dikeringkan diambil sebanyak 10 gram di masukkan ke dalam waring, disimpan pada ekosistem lamun diletakkan selama 1 bulan dengan waktu pengamatan per 7 hari kemudian diambil diamati bobot keringnya, (Awaliah, 2016).

\subsubsection{Pengukuran Kualitas Perairan}

Parameter perairan yang diukur berupa parameter fisika, kimia, seperti suhu, kecerahan, kecepatan arus, substrat, kedalaman, pH, salinitas, dan DO. Parameter kualitas perairan yang di ukur dapat di lihat pada Tabel 1.

Tabel 1. Pengukuran Parameter Kualitas Perairan

\begin{tabular}{clcc} 
No & \multicolumn{1}{c}{ Parameter } & Alat & Keterangan \\
\hline 1 & Fisika & & \\
& Suhu & Multitester & Insitu \\
& Kecerahan & Secchi disk & Insitu \\
& Kedalaman & Tongkat berskala & Insitu \\
& Substrat & Sekop & Insitu \\
& Kimia & & \\
pH & & Insitu \\
& Salinitas & Multitester & Insitu \\
& Do & Hand refractometer & Insitu \\
& Nitrat $\left(\mathbf{N O}_{3}\right)$ & Multitester & Laboratorium \\
& Fosfat $\left(\mathbf{P O}_{4}\right)$ & Spektrofotometer & Laboratorium \\
\hline
\end{tabular}

\subsection{Analisis Data}

Analisa data primer adalah dengan pengolahan data menggunakan rumus sebagai berikut :

\subsubsection{Tutupan Lamun}

Penutupan jenis merupakan perbandingan antara luas area yang ditutupi oleh jenis lamun ke-i dengan jumlah total area yang ditutupi lamun. Penutupan jenis lamun dapat dihitung dengan persamaan (KEPMEN LH No. 200/2004).

$$
C=\frac{\Sigma(M i x F i)}{\Sigma f}
$$

Keterangan :

$\mathrm{C} \quad=$ Presentase penutupan lamun $i$,

$\mathrm{Mi} \quad=$ Presentase titik tengah dari kelas kehadiran jenis lamun $i$,

$\mathrm{Fi} \quad=$ Frekuensi munculnya kelas penutupan ke- $i$

$F \quad=$ banyaknya sub petak dimana kehadiran jenis lamun $i$,

Tabel 2. Kategori Tutupan Lamun

\begin{tabular}{cc} 
Kondisi & Penutupan (\%) \\
Baik & $\geq 60$ \\
Sedang & $30-59,9$ \\
Rusak & $\leq 29,9$ \\
\hline
\end{tabular}

Sumber: KEPMEN LH No. 200 Tahun 2004.

\subsubsection{Produksi Serasah}

Produksi serasah dihitung berdasarkan berat serasah yang terapung dan tenggelam yang berada di dalam kurungan dengan kerapatan yang berbeda pada setiap 7 hari masa inkubasi (Awaliah, 2016).

$$
p=\frac{w}{D i}
$$

Keterangan :

$\mathrm{P} \quad=$ Produksi serasah (gram berat kering gbk $\left./ \mathrm{ind} / \mathrm{m}^{2}\right)$

$w \quad=$ Berat serasah (gbk)

$\mathrm{Di} \quad=$ Kerapatan lamun jenis ke-i (ind) 


\subsubsection{Laju Dekomposisi}

Sampel serasah yang akan didekomposisi terlebih dahulu dibuat sampel standar untuk mengetahui rasio antara berat kering, berat basah, dan kandungan air (Awaliah, 2016).

$$
\boldsymbol{r}=\frac{\boldsymbol{B} \boldsymbol{K}}{\boldsymbol{B} \boldsymbol{B}}
$$

Keterangan:

$r \quad=$ rasio berat kering dan berat basah

$B K=$ Berat Kering (gbk)

$\mathrm{BB}=$ Berat Basah

$$
k=100-(r \times 100 \%)
$$

Keterangan:

$k=$ Kandungan air (\%)

$r \quad=$ rasio berat kering dan berat basah

Laju dekomposisi dapat dihitung berdasarkan persen pengurangan berat pada setiap lamanya inkubasi (Juman, 2005).

$$
R=\frac{I W-F W}{D}
$$

\section{Keterangan:}

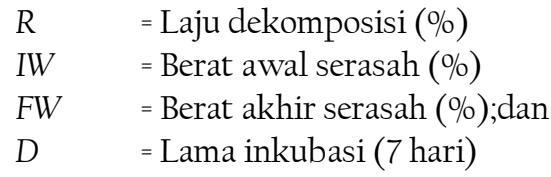

Pendugaan nilai konstanta laju dekomposisi serasah dengan menggunakan rumus (Ashton et al., 1999).

$$
\begin{gathered}
X t=X 0 . e^{-k t} \\
\ln (X t / X O)=-k t
\end{gathered}
$$

Keterangan:

$\chi_{t}=$ Berat kering serasah setelah waktu pengamatan $\mathrm{ke}-\mathrm{t}(\mathrm{g})$

$x_{0} \quad=$ Berat kering serasah awal (gram)

e $\quad=$ Bilangan logaritma natural $(2,72)$

$k=$ Konstanta laju dekomposisi serasah

$t \quad=$ Waktu pengamatan (hari)

\section{HASIL DAN PEMBAHASAN}

\subsection{Kondisi Umum Wilayah Penelitian}

Perairan Desa Malang Rapat merupakan salah satu wilayah yang termasuk kedalam wilayah Kabupaten Bintan dengan luas wilayah 771.225 Ha. Banyaknya jumlah penduduk yang ada di Desa Malang Rapat sekitar 2.079 jiwa, terletak di RT 01/RW02. Dengan batas - batas wilayah sebagai berikut:

Sebelah Utara : Desa Berakit

Sebelah Selatan : Kecamatan Teluk Bakau

Sebelah Timur : Laut Cina Selatan

Sebelah Barat : Toapaya Utara

Perairan Desa Malang Rapat merupakan perairan landai. Sebagian memanfaatkan hasil laut berupa kerang untuk memenuhi kebutuhan. Selain itu wilayah Desa Malang Rapat dijadikan sebagai kawasan wisata sehingga banyak dikunjungi wisatawan lokal maupun mancanegara untuk menikmati keindahan lautnya. Secara umum perairan Desa Malang Rapat memiliki lingkungan yang didominasi oleh keberadaan ekosistem lamun, substratnya didominasi pasir berlumpur.

\subsection{Parameter Lingkungan Perairan}

Kondisi lingkungan perairan mempengaruhi kehidupan baik secara langsung maupun tidak langsung. Sejumlah parameter lingkungan perairan sangat berpengaruh terhadap pertumbuhan lamun. Nilai-nilai 
parameter lingkungan perairan menggambarkan kualitas perairan yang dapat mendukung keberadaan ekosistem lamun. Parameter perairan yang diukur yaitu substrat, suhu, salinitas, DO, pH, kecerahan, kecepatan arus, kedalaman, nitrat, fosfat dan substrat atau sedimen hasil pengukuran disajikan didalam Tabel 3.

Tabel 3. Parameter Lingkungan Perairan

\begin{tabular}{|c|c|c|c|c|}
\hline \multirow{2}{*}{ Parameter } & \multirow{2}{*}{ Satuan } & \multicolumn{2}{|c|}{ Stasiun } & \multirow{2}{*}{ Baku Mutu* } \\
\hline & & 1 & 2 & \\
\hline \multicolumn{5}{|l|}{ Fisika } \\
\hline Suhu & ${ }^{\circ} \mathrm{C}$ & $30,60 \pm 0,10$ & $29,87 \pm 0,65$ & $28-30$ \\
\hline Kecerahan & $\mathrm{m}$ & $100 \pm 0$ & $100 \pm 0$ & \\
\hline Kedalaman & $\mathrm{cm}$ & $49,33 \pm 7,02$ & $53,33 \pm 1,53$ & \\
\hline \multicolumn{5}{|l|}{ Kimia } \\
\hline Salinitas & $\mathrm{o} / \mathrm{oo}$ & $32,67 \pm 0,58$ & $31,33 \pm 1,15$ & $33-34$ \\
\hline Derajat keasaman $(\mathrm{pH})$ & - & $7,5 \pm 0,20$ & $8,1 \pm 0,40$ & $7-8,5$ \\
\hline Oksigen terlarut (DO) & $\mathrm{mg} / \mathrm{L}$ & $7,73 \pm 0,21$ & $7,60 \pm 0,20$ & $>5$ \\
\hline Nitrat & $\mathrm{mg} / \mathrm{L}$ & $0,008 \pm 0,002$ & $0,007 \pm 0,001$ & 0,008 \\
\hline Fosfat & $\mathrm{mg} / \mathrm{L}$ & $0,009 \pm 0,003$ & $0,010 \pm 0,002$ & 0,015 \\
\hline
\end{tabular}

Sumber : Data primer

*Keputusan Menteri Lingkungan Hidup No 51 Tahun 2004.

Suhu merupakan salah satu faktor yang sangat penting dalam mengatur proses kehidupan dan penyebaran organisme, tinggi rendahnya suhu tersebut bisa disebabkan oleh kedalaman perairan pada tiap lokasi pengambilan sampel juga menyatakan bahwa semakin dalam suatu perairan maka suhu akan semakin rendah sedangkan semakin dangkal suatu perairan maka suhunya semakin tinggi, (Supiyati et al., 2012). Hasil pengukuran suhu perairan pada stasiun satu didapatkan nilai berkisar $30,60{ }^{\circ} \mathrm{C}$. Stasiun dua diperoleh nilai sebesar $29,87^{\circ} \mathrm{C}$. Kisaran suhu tersebut merupakan kisaran normal untuk daerah tropis dan masih dalam rentang toleransi untuk biota laut sesuai standar baku mutu yang ditetapkan oleh Kementerian Lingkungan Hidup (2004) yakni antara $28-32{ }^{\circ} \mathrm{C}$. sedangkan untuk fotosintesis lamun membutuhkan suhu optimum antara $25-35^{\circ} \mathrm{C}$ dan pada saat cahaya penuh (Salmin, 2005).

Hasil yang diperoleh nilai kecerahan yang sangat tinggi yaitu $100 \%$, berarti bahwa pada lokasi pengamatan penyinaran sinar masih terjadi sampai $100 \%$. Lamun membutuhkan intensitas cahaya yang tinggi untuk melakukan proses fotosintesis, distribusi lamun tergantung beberapa faktor, salah satunya adalah faktor kecerahan (dengan kedalaman < 10 m), (Ati et al., 2016). Kecerahan tentunya mendukung kelangsungan proses fotosintesis lamun. Nilai kecerahan di perairan Desa Malang Rapat tergolong baik bagi pertumbuhan lamun, kondisi kecerahan yang tinggi menguntungkan bagi lamun karena proses fotosintesis dapat berlangsung secara optimal.

Kedalaman perairan di stasiun satu sebesar 49,33 cm dan pada stasiun dua sebesar 53,33 cm. Menurut (Ruswahyuni \& Widyorini, 2014), cahaya matahari dapat tembus kekolom air sampai dasar sehingga proses fotosintesis oleh padang lamun dapat berlangsung dengan baik. Ke dalaman sangat memengaruhi kehidupan organisme perairan, ke dalaman suatu perairan sangat erat hubungannya dengan penetrasi cahaya matahari ke dalam kolom air yang digunakan oleh tumbuhan berklorofil untuk proses fotosintesis. Tumbuhan tidak dapat hidup terus menerus tanpa adanya cahaya matahari yang cukup, penyinaran cahaya matahari akan berkurang secara cepat sesuai dengan makin tinggi ke dalaman laut, perairan dalam dan jernih proses fotosintesisnya hanya terdapat sampai kedalaman 200 meter saja.

Salinitas perairan Desa Malang Rapat berkisar antara 32,67\%o pada stasiun satu sedangkan stasiun dua 31,33\%o. Salinitas tertinggi dijumpai pada stasiun satu sedangkan salinitas terendah dijumpai pada stasiun dua. Data yang diperoleh dibandingkan dengan baku mutu air laut KEPMEN LH NO. 51 Tahun 2004. Dimana untuk parameter salinitas berkisar antara 33-34\%. Hal ini masih sesuai dengan salinitas alami yang dipengaruhi oleh kondisi musiman, salinitas yang baik terhadap kehidupan lamun berkisar antara 28-35\%o, (Poedjirahajoe et al., 2013). Hasil yang didapat tidak jauh dari baku mutu sehingga parameter salinitas di Desa Malang Rapat masih dapat dikategorikan baik.

Hasil pengukuran pH di Perairan Desa Malang Rapat pada stasiun satu memperlihatkan bahwa nilai $\mathrm{pH} 7,5$ sedangkan pada stasiun dua 8,1. Jika dibandingkan dengan Keputusan Menteri Lingkungan Hidup No 51 Tahun 2004 baku mutu yakni antara 7 - 8,5, angka tersebut memenuhi baku mutu Drajat keasaman ( $\mathrm{pH}$ ) mempunyai pengaruh yang sangat besar terhadap organisme perairan sehingga dipergunakan sebagai petunjuk untuk menyatakan baik buruk suatu perairan. $\mathrm{pH}$ yang optimal untuk air laut anatara 7,5-8,5. Kisaran $\mathrm{pH}$ yang baik untuk lamun ialah pada saat $\mathrm{pH}$ air laut 7,5-8,5 karena pada saat kondisi $\mathrm{pH}$ berada dikisaran tersebut maka ion yang dibutuhkan oleh lamun untuk fotosintesis dalam keadaan melimpah (Hoek et al., 2016).

Oksigen terlarut adalah kandungan oksigen yang terlarut dalam perairan yang merupakan suatu komponen utama bagi metabolisme organisme perairan yang digunakan untuk pertumbuhan, reproduksi, dan kesuburan lamun (Prabowo $\&$ Dewi, 2015). Hasil pengukuran oksigen terlarut (DO) pada stasiun satu 7,73 mg/L sedangkan untuk stasiun dua 7,60 mg/L hal ini menunjukan nilai DO dalam kondisi yang baik hal tersebut didukung dengan pernyataan Keputusan Menteri Lingkungan Hidup No 51 Tahun 2004 bahwa oksigen terlarut (DO) di perairan yang mendukung untuk biota laut adalah $>5 \mathrm{mg} / \mathrm{L}$. Oksigen terlarut merupakan salah satu faktor yang penting dalam kehidupan organisme untuk proses respirasi. 
Berdasarkan hasil pengukuran nitrat di perairan Desa Malang Rapat di dapatkan hasil keseluruhan dari stasiun sebesar 0,007-0,008 mg/L. Bila dibandingkan dengan Keputusan Menteri Lingkungan hidup No 51 Tahun 2004 tentang baku mutu nitrat untuk biota laut sebesar 0,008 $\mathrm{mg} / \mathrm{L}$, kisaran nilai nitrat pada semua stasiun memenuhi baku mutu atau dapat dikatakan masih mendukung pertumbuhan lamun. Ketersediaan nitrat di perairan padang lamun dapat berperan sebagai faktor penting untuk melihat produktivitas primer padang lamun dan organisme autotrofnya, sumber utama nitrat berasal dari buangan rumah tangga, pertanian, kotoran hewan dan manusia. Selain itu sumber nitrat di perairan juga berasal dari limbah yang mengandung senyawa nitrat berupa bahan organik dan senyawa anorganik seperti pupuk nitrogen dan masukan dari air tawar (Subiakto et al., 2019).

Pengukuran fosfat di perairan Desa Malang Rapat diperoleh hasil sebesar 0,009-0,010 mg/L dan memenuhi kriteria baku mutu yaitu 0,015 mg/L (KEPMEN LH. No 51 Tahun 2004). Tinggi rendahnya kadar fosfat di suatu perairan adalah salah satu indikator untuk menentukan kesuburan suatu perairan. Pengaruh daratan terhadap masukan fosfat ke perairan tersebut terlihat sangat besar, selain secara alami sumber fosfat di perairan berasal dari sumber aktivitas manusia seperti buangan limbah (Meirinawati \& Muchtar, 2017).

\subsection{Substrat}

Hasil pengukuran klasifikasi tipe substrat yang dilakukan di Laboratorium Fakultas Ilmu Kelautan dan Perikanan Universitas Maritim Raja Ali Haji pada semua stasiun yaitu di dominasi oleh pasir berlumpur. Hasil pengukuran tipe substrat di perairan Desa Malang Rapat disajikan dalam Tabel 4.

Tabel 4. Hasil Pengukuran Tipe Substrat

\begin{tabular}{cccc} 
Stasiun & Kerikil \% & $\begin{array}{c}\text { Fraksi } \\
\text { Pasir \% }\end{array}$ & Lumpur \% \\
Stasiun 1 & 0 & 86,5 & 13,5 \\
Stasiun 2 & 0 & 85,3 & 14,7 \\
\hline
\end{tabular}

Berdasarkan data pada Tabel 4 menunjukkan tipe substrat di Desa Malang Rapat. Pada stasiun satu tipe substrat pasir dengan persentase $86,5 \%$ sedangkan lumpur $13,5 \%$, stasiun dua memiliki tipe substrat pasir dengan presentase $85,3 \%$, sedangkan lumpur $14,7 \%$ dimana lokasi tersebut yang merupakan perairan terbuka menyebabkan pergerakan arus terus menerus sehingga membuat pengadukan sedimen dapat berlangsung secara maksimal. (Nybakken, 1992) menyatakan substrat pasir pada umumnya miskin akan organisme, tidak dihuni oleh kehidupan makroskopik. Pantai berpasir tidak menyediakan substrat yang tetap untuk melekat bagi organisme.

\subsection{Tutupan Lamun}

Berdasarkan hasil persentase tutupan lamun yang ditemukan di lokasi penelitian di perairan Desa Malang Rapat Kecamatan Gunung Kijang Kabupaten Bintan dapat dilihat pada Gambar 4 dan Gambar 5.

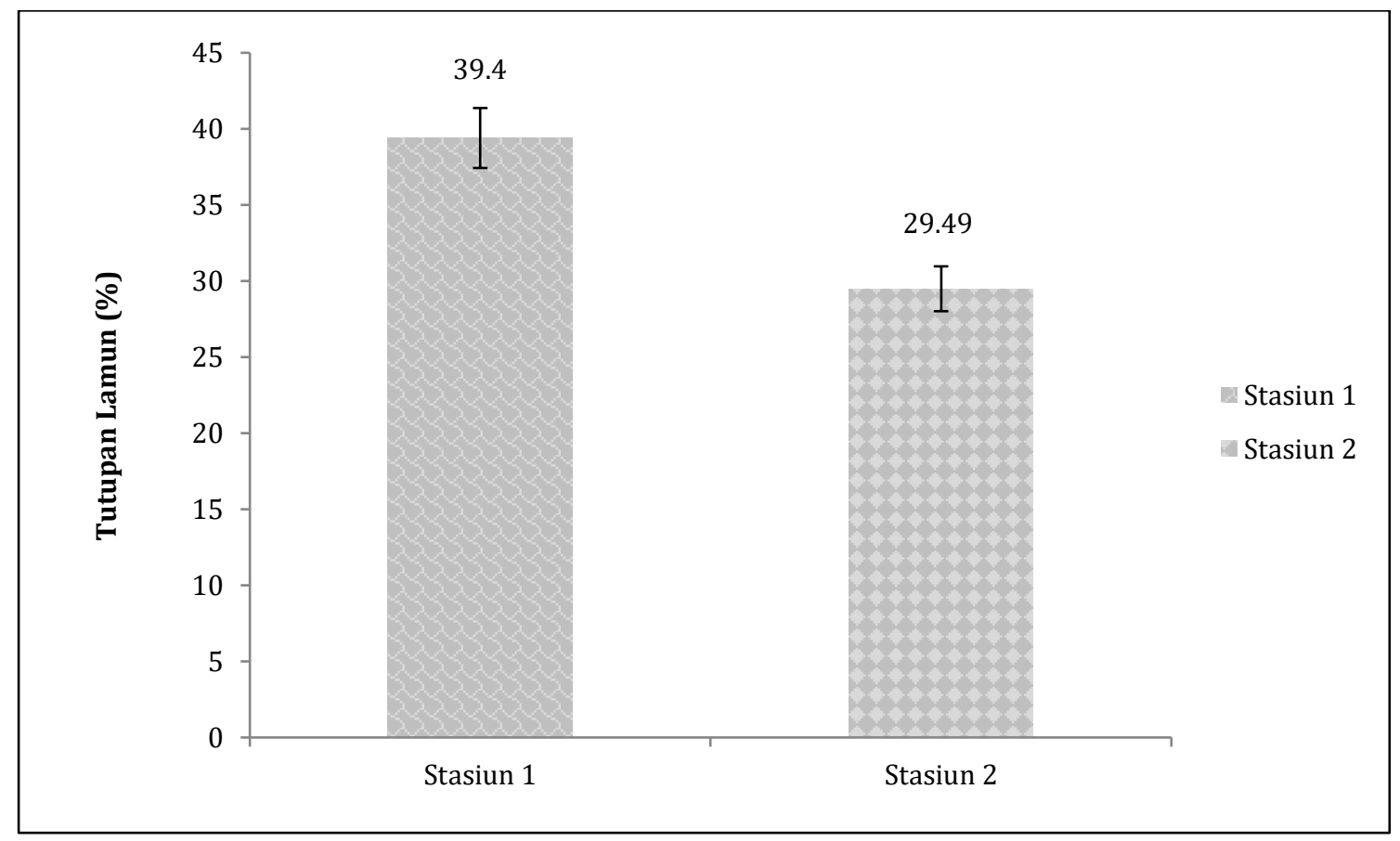

Gambar 4. Total Tutupan Lamun 


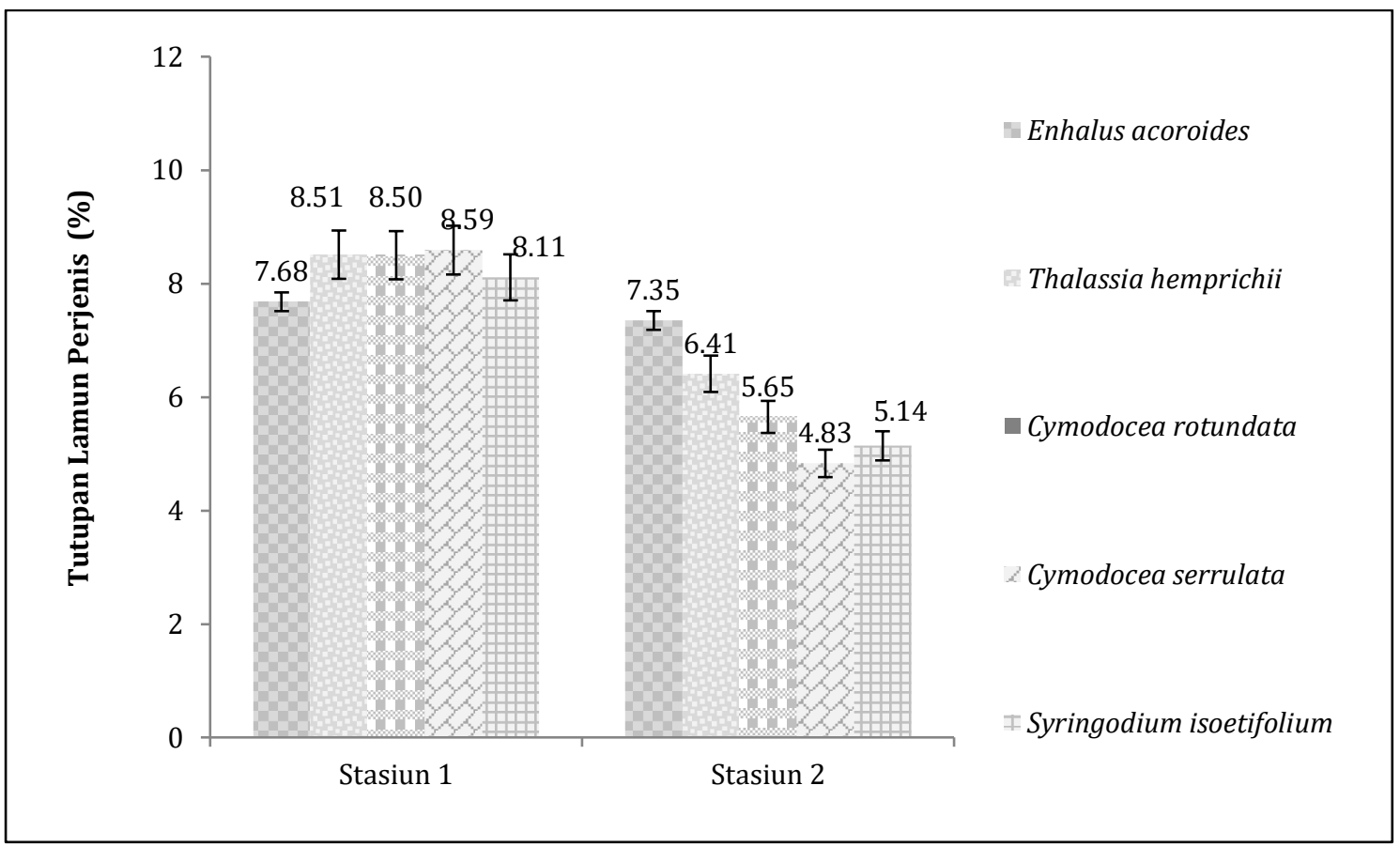

Gambar 5. Tutupan Lamun Perjenis

Berdasarkan nilai total tutupan lamun yang diperoleh pada setiap stasiun dapat diketahui bahwa kondisi dari setiap stasiun berada dalam kondisi sedang. Menurut KEPMEN LH NO. 200 Tahun 2004 kategori tutupan lamun $\geq 60$ kategori baik, 30-59,9 kategori sedang dan $\leq 29,9$ kategori rusak. Pada stasiun satu jenis E. acoroides sebesar 7,68\%, T. hemprichii sebesar 8,51\%, C. rotundata sebesar 8,50\%, C. serrulata sebesar 8,59\%, dan S. isoetifolium sebesar 8,11\% sedangkan pada stasiun dua jenis E. acoroides sebesar 7,35\%, T. hemprichii sebesar 6,41\%, C. rotundata sebesar 5,65\%, C. serrulata sebesar 4,83\%, dan S. isoetifolium sebesar 5,14\%.

Faktor yang memengaruhi tutupan lamun antara lain, kemampuan adaptasinya terhadap tipe substrat, nutrien, suhu, salinitas, menyebabkan tingginya nilai penutupan lamun (Takaendengan \& Azkab, 2010). Ketersediaan nutrien di perairan padang lamun dapat berperan sebagai faktor pembatas pertumbuhan. Semakin banyaknya aktivitas di sepanjang wilayah pesisir akan menyebabkan terganggunya lamun, dan tingginya kadar salinitas, suhu dan tipe substrat juga dapat memengaruhi rendahnya tutupan lamun (Aziizah et al., 2016).

\subsection{Produksi Serasah}

Hasil pengamatan produksi serasah lamun pada stasiun satu yang ditemukan di lokasi penelitian di perairan Desa Malang Rapat Kecamatan Gunung Kijang Kabupaten Bintan dapat dilihat pada Gambar 6.

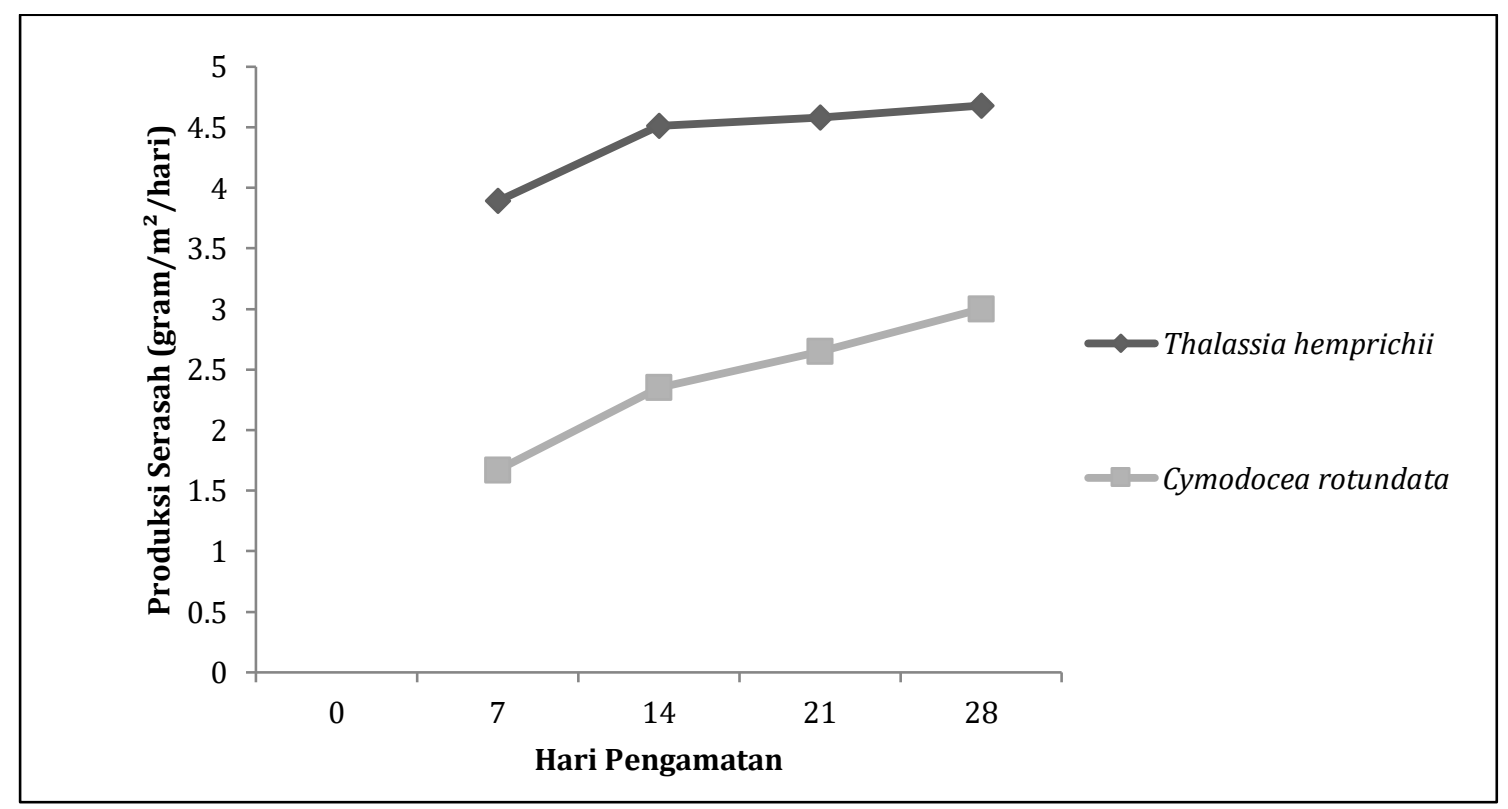

Gambar 6. Produksi Serasah Stasiun 1 
Hasil rata-rata pengukuran di lokasi penelitian pada stasiun satu jenis T. hemprichii pada hari ke-7 sebesar 3,89 gram $/ \mathrm{m}^{2} /$ hari, hari ke-14 sebesar 4,51 gram $/ \mathrm{m}^{2} /$ hari, pada hari ke-2l sebesar 4,58 gram/ $/ \mathrm{m}^{2} /$ hari dan pada hari ke-28 sebesar 4,68 gram $/ \mathrm{m}^{2} /$ hari,sedangkan C. rotundata pada hari ke-7 sebesar 1,67 gram $/ \mathrm{m}^{2} /$ hari, pada hari ke-14 sebesar 2,35 gram $/ \mathrm{m}^{2} /$ hari, hari ke-2l sebesar 2,65 gram $/ \mathrm{m}^{2} /$ hari dan pada hari ke-28 sebesar 3,0 gram $/ \mathrm{m}^{2} /$ hari.

Hasil pengamatan produksi serasah pada stasiun dua di perairan Desa Malang Rapat Kecamatan Gunung Kijang Kabupaten Bintan dapat dilihat pada Gambar 7.

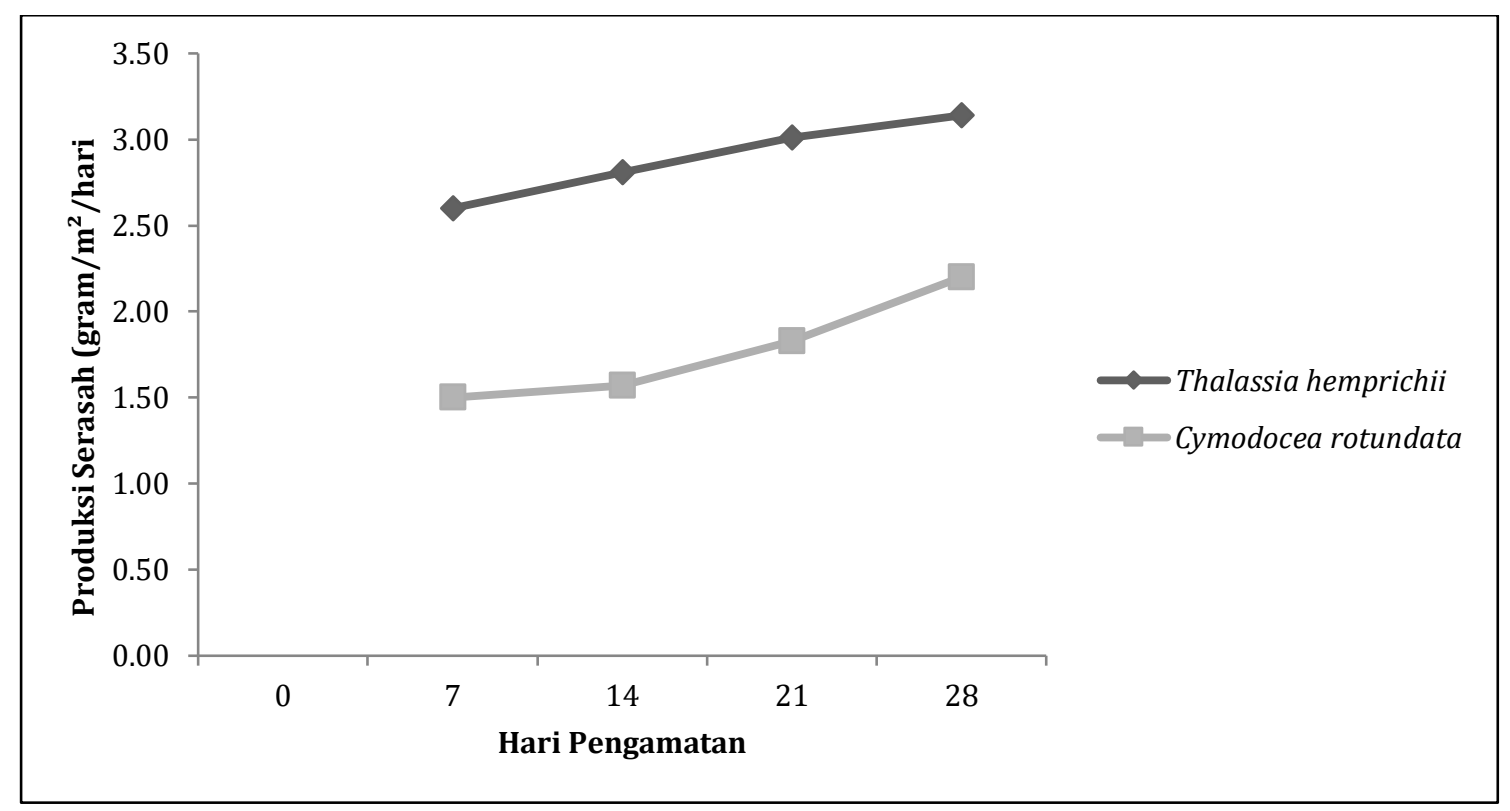

Gambar 7. Produksi Serasah Stasiun 2

Pada stasiun dua jenis T. hemprichii pada hari ke-7 sebesar 2,60 gram $/ \mathrm{m}^{2} /$ hari, pada hari ke-14 sebesar 2,81 gram $/ \mathrm{m}^{2} /$ hari, hari ke-2l sebesar 3,0l gram $/ \mathrm{m}^{2} /$ hari dan pada hari ke- 28 sebesar $3,14 \mathrm{gram} / \mathrm{m}^{2} /$ hari. sedangkan C. rotundata pada hari ke-7 sebesar 1,50 gram $/ \mathrm{m}^{2} /$ hari, hari ke-14 sebesar $1,57 \mathrm{gram} / \mathrm{m}^{2} /$ hari, hari ke-2l sebesar $1,83 \mathrm{gram} / \mathrm{m}^{2} /$ hari dan hari ke-28 sebesar 2,2 gram $/ \mathrm{m}^{2} /$ hari.

Produksi serasah daun lamun dipengaruhi oleh beberapa faktor lingkungan perairan di antaranya ketersediaan nitrat dan fosfat, tipe substrat dan karakteristik dari jenis lamun, kecerahan dan musim (hujan, kecepatan angin dan gelombang) (Supriyadi \& Kuriandewa, 2013). Lamun jenis T. hemprichii memiliki ukuran morfologi daun tebal dan besar serta menyukai tipe substrat pasir berlumpur sedangkan C. rotundata memiliki morfologi daun tipis, panjang, kecil dan ramping hidup pada substrat pasir berlumpur. Lamun dengan bentuk ukuran yang lebih besar akan memiliki produksi yang lebih tinggi dibandingkan dengan lamun yang morfologinya kecil. Selain faktor morfologi lamun, produksi lamun juga dipengaruhi oleh luas area padang lamun (Kiswara, 2010). Pengaruh kecepan angin dan suhu udara yang tinggi dan penyinaran yang lama dapat menyebabkan pengguguran daun dalam jumlah yang banyak untuk mencegah transpirasi yang tinggi (Patty, 2010).

Seiring waktu produksi serasah terus menigkat hal ini sejalan dengan semakin tinggi tutupan lamun maka semakin tinggi produksi serasah begitu pula sebaliknya semakin rendah tutupan lamun maka semakin rendah produksi serasahnya. Tinggi nilai produktivitas serasah daun lamun ini juga dipengaruhi oleh morfologi serasah daun pada daun tua memiliki produksi serasah lebih besar dibandingkan serasah daun lamun yang masih muda dan serasah daun setengah tua yang diduga karena morfologi serta kandungan unsur hara yang berbeda di setiap jaringan daun (Santoso et al., 2018). Serasah yang mengendap dimanfaatkan oleh fauna bentik dan partikel-partikel serasah dimanfaatkan oleh organisme penyaring (filterfeeder) (Irawan, 2017). Sebagai perbandingan dari penelitian (Awaliah, 2016), produksi serasah E. acoroides lebih banyak dibandingkan serasah C. rotundata. Produksi serasah E.acoroides terbanyak yaitu di Stasiun E2 dengan kerapatan $36 \mathrm{ind} / \mathrm{m}^{2}$ sebesar $0,0239 \mathrm{gbk} / \mathrm{ind} / \mathrm{m}^{2}$.

\subsection{Laju Dekomposisi}

Hasil pengamatan persen pengurangan berat serasah lamun pada stasiun satu yang ditemukan di lokasi penelitian di perairan Desa Malang Rapat Kecamatan Gunung Kijang Kabupaten Bintan pada stasiun satu dapat dilihat pada Gambar 8. 


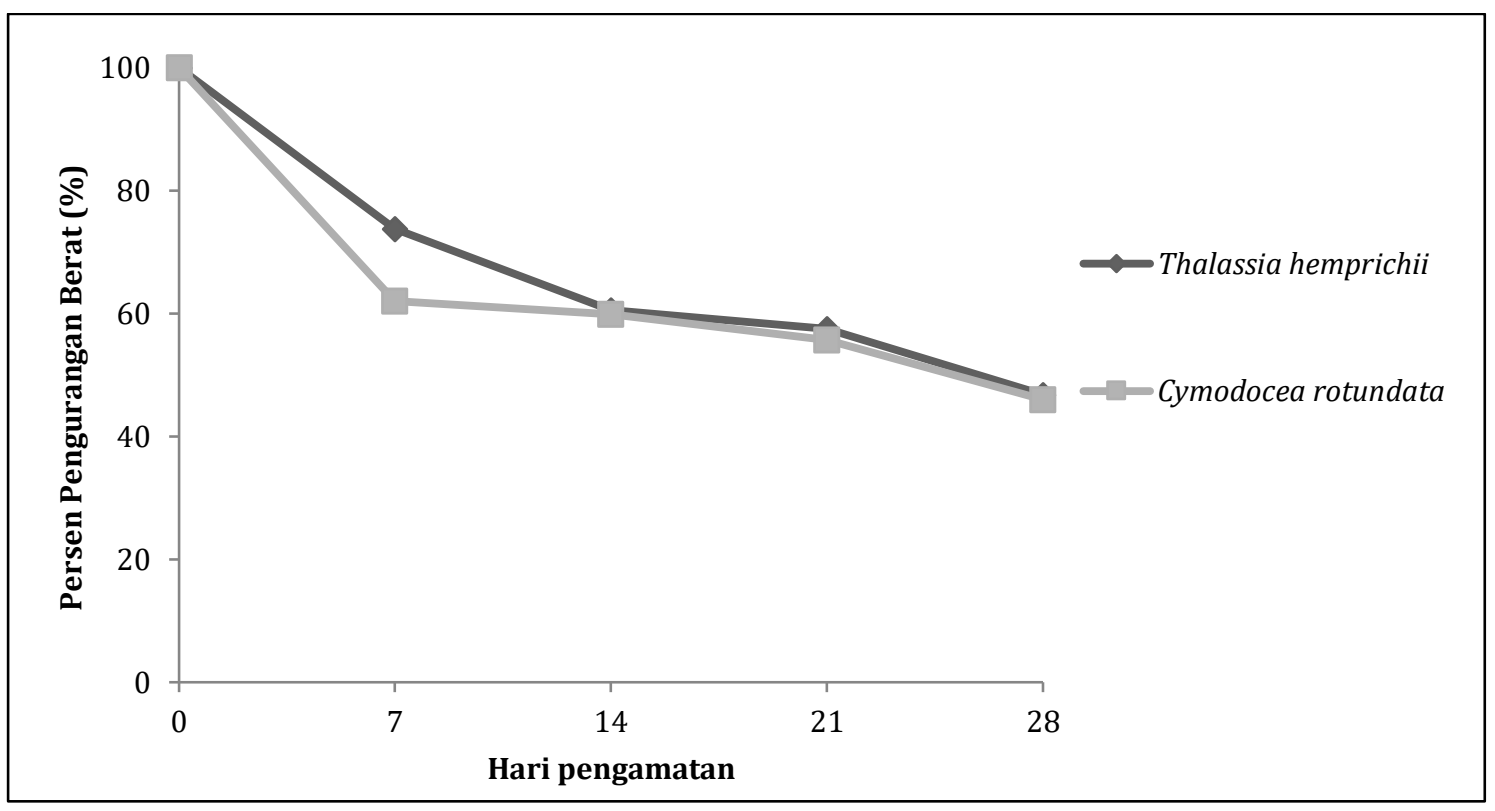

Gambar 8. Persen Pengurangan Berat Serasah Lamun Stasiun 1

Berdasarkan hasil pengamatan persen pengurangan berat serasah lamun pada stasiun satu untuk jenis T. hemprichii pada hari ke-7 sebesar 73,8\%, hari ke-14 sebesar 60,6\%, hari ke-21 sebesar 57,5\% dan hari ke-28 sebesar 46,8\%. sedangkan C. rotundata pada hari ke-7 sebesar 62,0\%, hari ke-14 sebesar 59,9\%, hari ke-21 sebesar 55,7\% dan untuk hari ke-28 sebesar $46 \%$.

Hasil pengamatan persen pengurangan berat serasah lamun pada stasiun dua di perairan Desa Malang Rapat Kecamatan Gunung Kijang Kabupaten Bintan dapat dilihat pada Gambar 9.

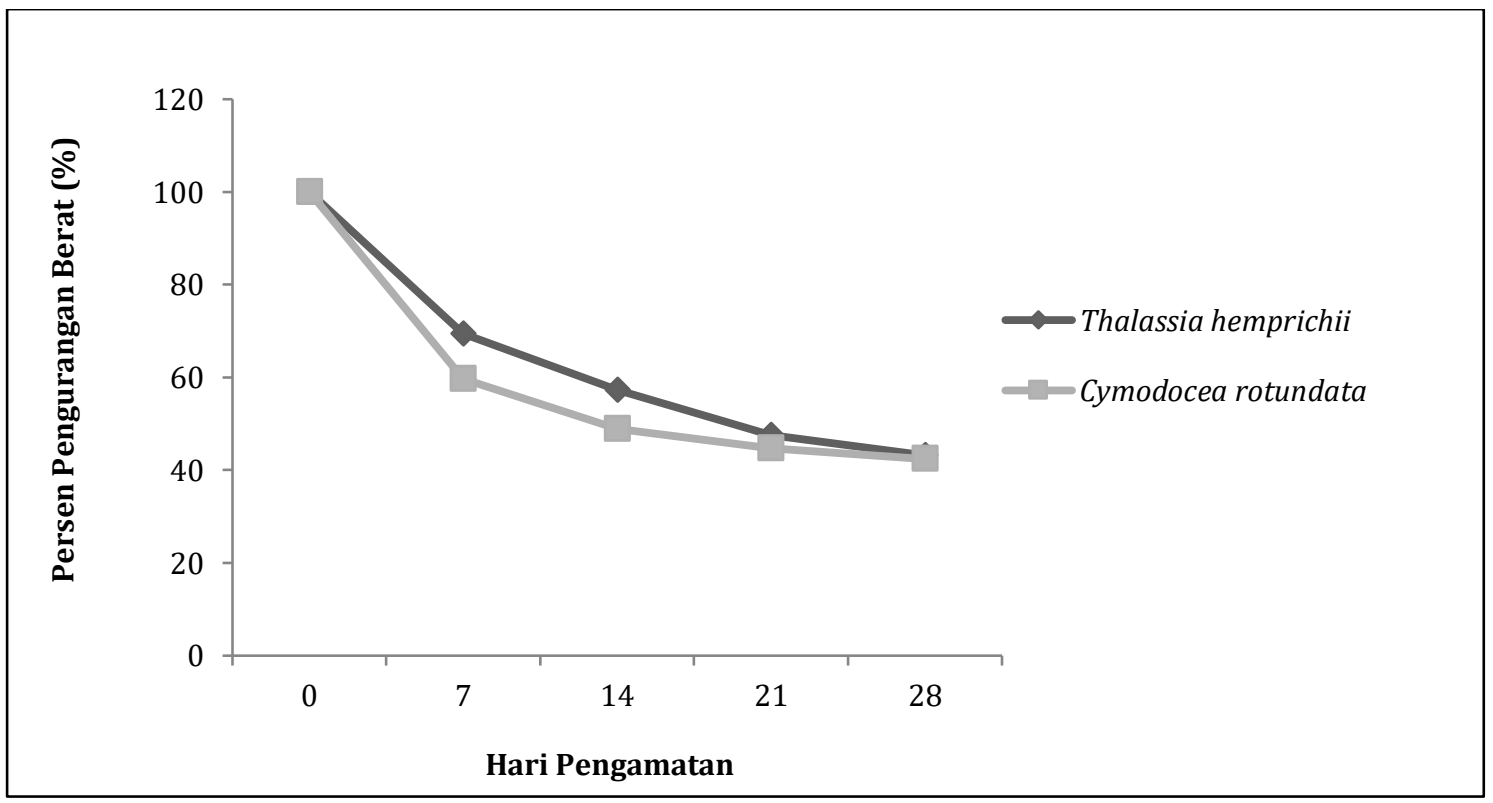

Gambar 9. Persen Pengurangan Berat Serasah Lamun Stasiun 2

Hasil pengamatan persen pengurangan berat serasah lamun pada stasiun dua jenis T. hemprichii pada pengamatan hari ke- 7 sebesar 69,5\%, pada hari ke-14 sebesar 57,3\%, hari ke-21 sebesar 47,6\% dan hari ke-28 sebesar 43,2\%. sedangkan C. rotundata pada pengamatan hari ke- 7 sebesar 59,7\%, hari ke-14 sebesar 48,9\%, hari ke-2l sebesar 44,7\% dan pada hari ke-28 sebesar $42,4 \%$.

Faktor yang mempengaruhi persen pengurangan berat serasah ini diduga karena adanya penurunan aktivitas dari bakteri yang terlibat proses dekomposisi, serasah yang terputus tidak langsung mengalami pelapukan oleh mikroorganisme tetapi memerlukan bantuan makrozobentos. Makrozobentos berperan sebagai dekomposer awal yang bekerja dengan cara mencacah daun menjadi bagian-bagian kecil yang kemudian dilanjutkan oleh organisme kecil yakni mikroorganisme (bakteri dan Fungi) yang menguraikan bahan organik menjadi protein dan karbohidrat (Kaswadji et al., 2012). Perbandingan dari penelitian (Awaliah, 2016), serasah C. rotundata kehilangan berat mencapai lebih dari 50\% dalam waktu 14 hari dan lebih cepat kehilangan berat dibandingkan E. acoroides. 
Laju dekomposisi serasah lamun pada stasiun satu di perairan Desa Malang Rapat Kecamatan Gunung Kijang Kabupaten Bintan dapat dilihat pada Gambar 10.

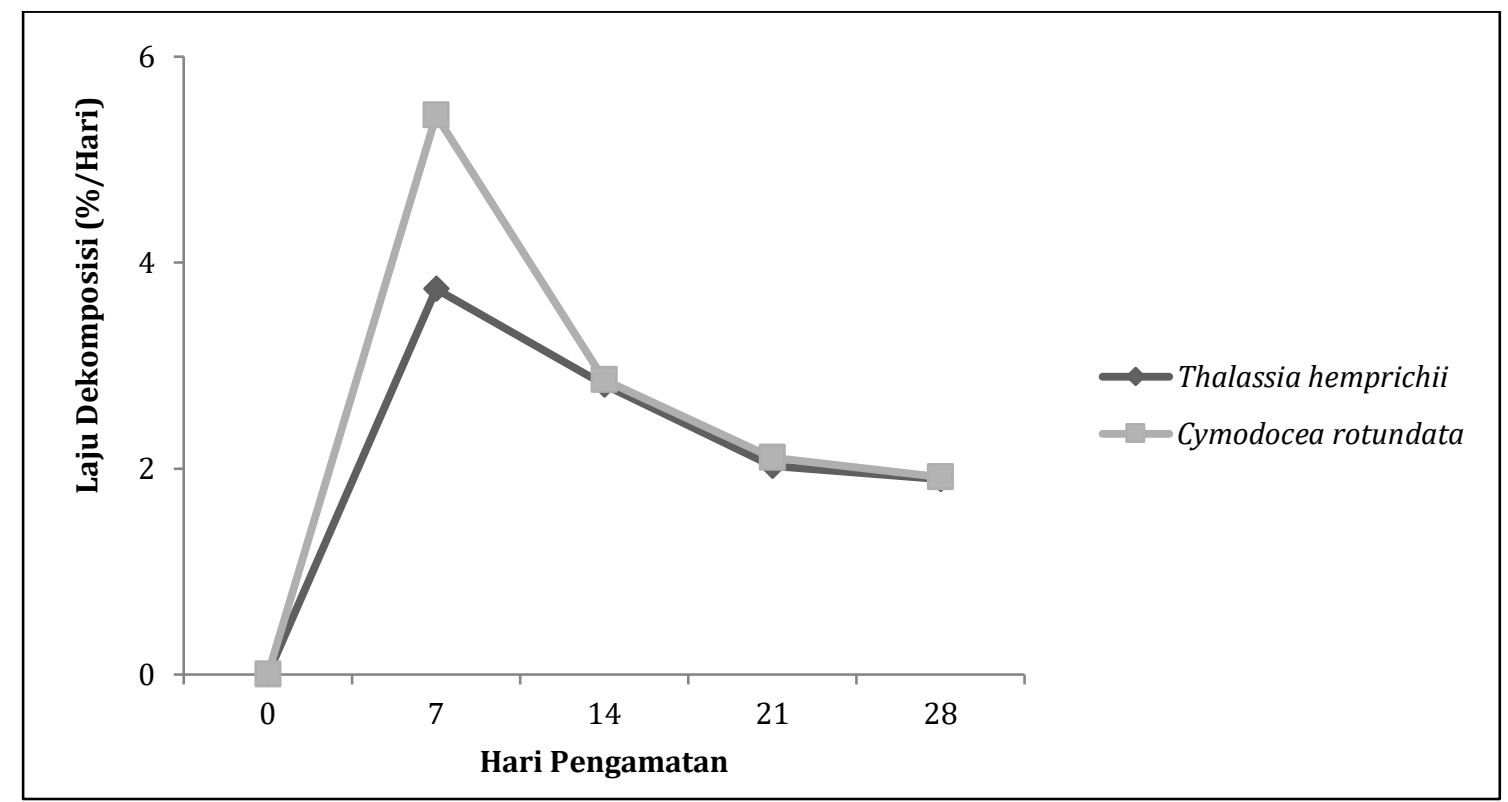

Gambar 10. Laju Dekomposisi Serasah Lamun Stasiun 1

Hasil laju dekomposisi serasah lamun pada stasiun satu jenis T. hemprichii dilihat pada hari ke-7sebesar 3,74\%/hari, pada hari ke-14 terjadi penurunan sebesar 2,81\%/hari, pada hari ke-21 sebesar 2,02\%/hari dan pada hari ke-28 sebesar 1,90\%/hari sedangkan C. rotundata pada hari ke-7 sebesar 5,43\%/hari, hari ke-14 sebesar 2,86\%/hari, pada hari ke-21 sebesar 2,11\%/hari dan hari ke-28 sebesar 1,92\%/hari, laju dekomposisi mengalami penurunan setiap harinya.

Hasil pengamatan laju dekomposisi stasiun dua di perairan Desa Malang Rapat Kecamatan Gunung Kijang Kabupaten Bintan dapat dilihat pada Gambar 11.

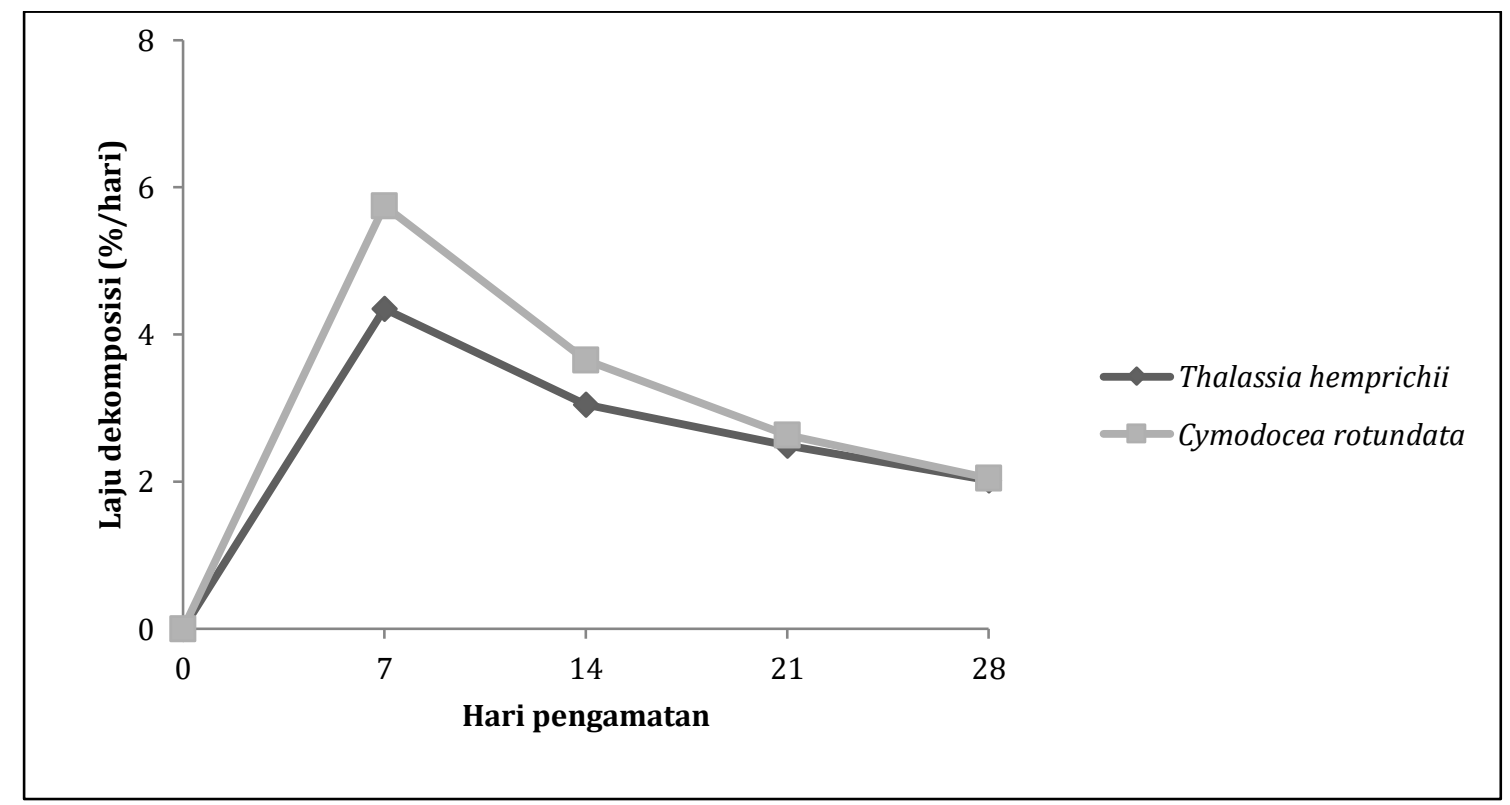

Gambar 11. Laju Dekomposisi Serasah Lamun Stasiun 2

Laju dekomposisi serasah lamun pada stasiun dua jenis T. hemprichii pada hari ke-7 sebesar 4,35\%/hari, hari ke-14 sebesar 3,05\%/hari, pada hari ke-21 sebesar 2,49\%/hari dan pada hari ke-28 sebesar 2,02\%/hari, sedangkan C. rotundata pada hari ke-7 sebesar 5,75\%/hari, pada hari ke-14 sebesar 3,65\%/hari, sedangkan pada hari ke-21 sebesar 2,63\%/hari dan untuk hari ke-28 sebesar 2,05\%/hari. Fakto waktu dalam pengukuran dekomposisi serasah daun berpengaruh terhadap laju penghancuran serasah. Karena faktor waktu berkaitan dengan faktor lingkungan, menurunya bahan organik, mikroorganisme yang berperan dalam perombakan beberapa zat yang terkandung dalam serasah daun lamun. Peningkatan suhu dapat merangsang kegiatan metabolisme mikroba untuk mempercepat lajunya proses dekomposisi akan terdapat suatu peningkatan didalam laju Dekomposisi (Zamroni \& Rohyani, 2008). 
Selanjutnya persamaan peluruhan daun lamun di seluruh stasiun disajikan pada Tabel 5.

Tabel 5. Persamaan Peluruhan Daun Lamun di Seluruh Lokasi Penelitian

\begin{tabular}{ccccc} 
Stasiun & Jenis & Persamaan Peluruhan & $\mathbf{R}^{2}$ & \multicolumn{1}{c}{ K } \\
$\mathbf{1}$ & Thalassia hemprichii & $83,979 \mathrm{e}^{-0,02 \mathrm{x}}$ & 0,9576 & 33,677 \\
$\mathbf{2}$ & Cymodocea rotundata & $70,75 \mathrm{e}^{-0,014 \mathrm{x}}$ & 0,8786 & 34,240 \\
& Thalassia hemprichii & $80,042 \mathrm{e}^{-0,023 \mathrm{x}}$ & 0,9801 & 34,411 \\
\hline
\end{tabular}

Berdasarkan nilai $\mathrm{R}^{2}$ mendekati satu artinya bahwa ada korelasi antara jumlah hari dengan dekomposisi, kemudian dari nilai $K$ ini semakin menguatkan bahwa C. rotunadata itu lebih cepat dari pada T. hemprichii meskipun selisihnya sangat sedikit. Pada Stasiun satu nilai $\mathrm{R}^{2}$ jenis T. hemprichii sebesar 0,9576, sedangkan nilai $K$ sebesar 33,527, nilai $\mathrm{R}^{2}$ jenis $C$. rotundata sebesar 0,8786 , sedangkan nilai $K$ sebesar 33,677. Stasiun dua nilai $\mathrm{R}^{2}$ jenis T. hemprichii sebesar 0,9801 , sedangkan nilai $K$ sebesar 34,240, nilai $\mathrm{R}^{2}$ jenis C. rotundata sebesar 0,9169, sedangkan nilai $K$ sebesar 34,41l. Seluruh stasiun memiliki laju dekomposisi yang tidak berbeda jauh, laju dekomposisi memiliki hubungan yang signifikan dengan suhu, substrat, dan salinitas. Menurut (Dharmawan et al., 2016) menjelaskan bahwa peluruhan serasah daun didefinisikan sebagai kehilangan berat akibat beberapa proses fisika-kimia yang disebabkan oleh kondisi lingkungan.

Faktor yang memengaruhi besarnya laju dekomposisi serasah dilihat dari ukuran morfologi daunnya, parameter lingkungan perairan seperti $\mathrm{pH}$, suhu, salinitas, gelombang, kecepatan arus, dan pasang surut. Daun T. hemprichii mengalami laju dekomposisi yang lebih lambat dibandingkan C. rotundata hal ini diduga luas permukaan daun yang lebih besar dan tebal, daun lamun yang memiliki ukuran lebih kecil, tipis akan cepat mengalami dekomposisi dibandingkan lamun yang memiliki ukuran yang lebih besar (Pratiwi et al., 2017).

Hasil penelitian (Awaliah, 2016). laju dekomposisi C. rotundata lebih cepat dibandingkan E. acoroides dengan laju tertinggi kedua spesies terjadi pada hari kedua. E. acoroides mengalami laju dekomposisi yang lebih lambat dibandingkan C. rotundata. Hal ini diduga luas permukaan daun yang lebih tebal, karakteristik fisik serta komposisi kimia daun.

\section{SIMPULAN}

Kesimpulan dari penelitian yang dilakukan di Perairan Desa Malang Rapat Kecamatan Gunung Kabupaten Bintan nilai tutupan lamun perjenis pada stasiun satu T. hemprichii dan C. rotundata lebih tinggi jika dibandingkan pada stasiun dua. Nilai total tutupan lamun setiap stasiun dikategorikan sedang. Produksi serasah pada stasiun satu jenis T. hemprichii dan C. rotundata lebih tinggi dibandingkan pada stasiun dua. Laju dekomposisi stasiun dua jenis T. hemprichii dan C. rotundata lebih cepat dibandingkan pada stasiun satu.

Saran yang dipertimbangkan untuk penelitian selanjutnya di wilayah ini yaitu, pada saat pemasangan perangkap serasah terlebih dahulu harus mengetahui pasang surut air laut, dan mengetahui musim angin agar memudahkan pada saat pemasangan perangkap. Mengidentifikasi permasalahan-permasalahan yang timbul dari aktivitas sekitar yang memberikan ancaman terhadap ekosistem lamun. Mengetahui jenis-jenis lamun yang dapat menggugurkan serasah yang lebih cepat. Untuk penyempurnaan penelitian ini yaitu perlu dilakukannya penelitian lebih lanjut mengenai produksi serasah dan laju dekomposisi daun dan rhizoma untuk semua jenis lamun yang ada di perairan Desa Malang Rapat sehingga hasil yang di dapatkan dapat maksimal.

\section{REFERENSI}

Asmidar. (2015). Analisis Hubungan Beberapa Faktor Fisika Oseanografi Dengan Kerapatan Ekosistem Lamun di Perairan Puntondo Kabupaten Takalar. Jurnal Octopus. 4(1): 358-364.

Asthon, E.C. (1999). Breakdown of Mangrove Leaf Litter in a Managed Mangrove Forest in Peninnsular Malaysia. In Hydrobiologia 413: 77-88.

Ati, R.N.A, Kepel, T.L., Kusumaningtyas, M.A., Hutahean,A.A., \& Mantiri, D.M.H. (2016). Karakteristik dan Potensi Perairan Sebagai Pendukung Pertumbuhan Lamun di Perairan Teluk Buyat dan Teluk Ratatotok. Sulawesi Utara. Jurnal Manusia dan Lingkungan. 23(2): 342-348.

Awaliah, S.M. (2016). Produksi Serasah dan Laju Dekomposisi Enhalus acoroides dan Cymodocea rotundata di Perairan Pulau Pari, Kepulauan Seribu. [Skripsi]. Fakultas Ilmu Perikanan dan Kelautan. Institut Pertanian Bogor.

Aziizah, N.N., Manuputty, A., Agus, S.B., \& Siregar,V.P. (2016). Analisis Spasial Luas Tutupan Lamun di Pulau Tunda Serang, Banten. Jurnal OmniAkuatika. 12(1): 73-80.

Badan Pusat Statistik (BPS) Kabupaten Bintan. (2015). Desa Malang Rapat. Kepulauan Riau.

Dharmawan, I.W.E., Maddupa, H.H., \& Zamani, N.P. (2016). Laju Dekomposisi Serasah Daun di Ekosistem Bakau Pulau Kelong. Kabupaten Bintan. Jurnal OSEANOLOGI dan LIMNOLOGI di Indonesia. 1(1): 1-10.

Faiqoh, E., Santoso, B., \& Dharma, I.G.B. (2018). Pertumbuhan dan Produktivitas Daun Lamun Thalassia hemprichii (Ehrenb) Ascherson di Perairan Tanjung Benoa. Bali. Journal Of Marine And Aquatic Seiences. 4(2): 279-285. 
Hoek, F., Arfah, A., Mustasim, Ulat, M.A., Suruwaky, A.M., Razak, A.D., Hamid, \& Muhfizar. (2016). Struktur Komunitas Lamun di Perairan Distrik Sulawati Utara. Kabupaten Raja Ampat. Jurnal Airaha. 5(1): 87-94.

Hutomo, M., \& Azkab, M.H. (1987). Peranan Lamun Di Lingkungan Laut Dangkal J Oseana. Balitbang Biologi Laut. Jurnal Pustlibang Biologi Laut-LIPI. 12(1): 13 - 23.

Irawan, A. (2017). Potensi Cadangan dan Serapan Karbon oleh Padang Lamun di bagian Utara dan Timur Pulau Bintan. Jurnal Oseanologi dan Limnologi di Indonesia. 2(3): 35- 48.

Juman, R.A. (2005). Biomass. Litterfall and Decomposition Rates for the Fringed Rhizophora mangle Forest Lining the Bon Accord Lagoon. Tobago. Rev. Biol. Trop.J.Trop. Biol. 53(1): 207-217.

Kaswadji, R.F., Bengen, D.G., \& Utomo, M. 2012. Produktivitas Komunitas Lamun di Pulau Baranglompo Makassar. Jurnal Akuatika. 3(2): $159-168$

Kawaroe, M., Nugraha, A.H., Juraij, \& Tasabaramo, I.A. (2016). Seagrass Biodiversity At Three Marine Ecoregions of Indonesia:Sunda Shelf, Sulawesi Sea, and Banda Sea. Jurnal BIODIVERSITAS. 17(2): 585-591.

Keputusan Menteri Negara Lingkungan Hidup (KEPMEN LH. No. 200. Tahun 2004.) Kriteria Baku Kerusakan dan Pedoman Penentuan Stastus Padang Lamun.

Keputusan Menteri Negara Lingkungan Hidup No. 51 Tahun 2004 tentang Baku Mutu Kualitas Air Laut Untuk Biota Laut. Jakarta.

Kiswara,W. 2010. Potensi Padang Lamun Sebagai Karbon Rosot dan Penyerapan Karbon di Pulau Pari, Teluk Jakarta. Jurnal oseanologi dan Limnologi di Indonesia. 36(3): 361-376.

Meirinawati, H., \& Muchtar, M. (2017). Fruktuasi Nitrat, Fosfat dan Silikat di Perairan Pulau Bintan. Jurnal Segera. 13(3): 141-148.

Nybakken, J.W. (1992). Biologi Laut Suatu Pendekatan Ekologis. PT. Gramedia. Jakarta.

Patty, W. (2010). Analisa Produktifitas dan Laju Dekomposisi Serasah Daun Mangrove di Desa Bahoi, Kabupaten Minahasa utara. Junal Chem. Prog. 3(2): 91-95.

Poedjirahajoe, E., Mahayani, B., NPD, Shidarta, R., \& Salamuddin, M. (2013). Tutupan Lamun dan Kondisi Ekosistemnya di Kawasan Pesisir Madasanger Jelenga Maluku. Kabupaten Sumbawa Barat. Jurnal Ilmu dan Teknologi Kelautan Tropis. 5(1): 36-46.

Prabowo, S.A., \& Dewi, N.K. (2015). Status Padang Lamun Pantai-Pantai Wisata di pacitan. Madiun. Jurnal Biogenesis. 3(1): 53-59.

Pratiwi, T.N., Hartati, R., \& Pratikto, I. (2017). Biomassa Dan Estimasi Simpanan Karbon Pada Lamun Di Pulau Menjangan Kecil dan Pulau Sintok, Kepulauan Karimunjawa. Jurnal Buletin Oseanografi Marina. 6(1): 74-81.

Ruswahyuni, M.H., \& Widyorini, N. (2014). Analisis Laju Sedimentasi di Dearah Padang Lamun Dengan Tingkat Kerapatan Berbeda di Pulau Panjang Jepara. Semarang. Jawa Tengah. Journal of Maquares. 3(3): 73-79.

Salmin. (2005). Oksigen Terlarut (DO) Dan Kebutuhan Oksigen Biologi (BOD) Sebagai Salah Satu Indikator Untuk Menentukan Kualitas Perairan. Jurnal Oseana. 30(3): 21-26.

Santoso, B., Dharma, I.G.B.S., \& Faiqoh, E. (2018). Pertumbuhan dan Produktivitas Daun Lamun Thalassia hemprichii (Ehnrenb) Ascherson di Perairan Tanjung Benao. Bali. Journal of Marine and Aquatic Sciences. 4(2): 278-285.

Subiakto, A.Y., Riniatsih, I., Santoso, G.W.S, \& Suryono. (2019). Hubungan Kandungan Nitrat dan Fosfat Dalam Substrat Terhadap Kerapatan Lamun Di Perairan Pantai Prawean . Jepara. Journal of Marine Research. 8(1): 55-61.

Supiyati, Halauddin, \& Arianty, G. (2012). Karakteristik dan Kualitas Air di Muara Sungai Hitam Provinsi Bengkulu dengan Software Som Toolbox 2. Jurnal Ilmu Fisika Indonesia. 1 (2): 67-73.

Supriadi, Kaswadji, R.F., Bengen, D.G., \& Hutomo, M. (2018). Produktivitas Komunitas Lamun di Pulau Barranglompo. Makassar. Jurnal Akuatika. 1(2): 159-168.

Supriyadi, I.H., \& Kuriandewa, T.E. (2013). Seagrass Distribution at Small Ialand Derawan Archipelago, East Kalimantan Province, Indonesia. Jurnal Oseanologi dan Limnologi. 34(1): 83-99.

Takaendengan, K., \& Azkab, M.H. (2010). Struktur Komunitas Lamun di Pulau Talise. Sulawesi Utara. Jurnal Oseanologi Limnologi di Indonesia. 36(1): 85-95.

Zamrony, Y., \& Rohyani, I. (2008). Produksi Serasah Hutan Mangrove di Perairan Pantai Teluk Sepi. Lombok Barat. Jurnal Biodiversitas. 9(4): 284-287. 